\title{
Analisis metode Sosiodrama dalam pembelajaran Aqidah Akhlak materi kerja keras dan mandiri
}

\author{
Nurjanah Wijayanti a,1,* \\ a SMP Muhammadiyah 1 Depok, Maguwoharjo Depok Sleman, Yogyakarta, 55282, Indonesia \\ ${ }^{1}$ nur905586@gmail.com \\ * corresponding author
}

\section{ARTICLE INFO}

\section{Article History}

Received: 13 oj January, 2021

Revised: 31 of January, 2021

Accepted: 31 of January, 2021

Keyword: Sociodrama Method, Learning Aqidah Akhlak, Hard work and independence

Kata Kunci: : Metode Sosiodrama, Pembelajaran Aqidah Akhlak, Kerja keras dan mandiri

\begin{abstract}
It can be said that education in Aqidah Akhlak is the basis for shaping student character or soft skills. The challenge faced in learning Akidah Akhlak is how students implement it, not only teaching knowledge about theory but how to direct students to have the quality of faith, piety and noble morals. The process of learning Akidah Akhlak should be implemented in real life. Therefore, it is important to strengthen the lesson of Aqidah Akhlak, it requires learning methods and strategies that are more complex and not monotonous. In this article, the authors analyze one of the active learning methods, namely the Sociodrama method on hard work and independent materials. This research is a research library research, using the content analysis method (content analysis), by analyzing two data sources, namely primary data and secondary data through descriptive analysis and interpretive approaches. The results of this study are the implementation of the Sociodrama method in learning Aqidah Akhlak, hard work and independent material, students can actively participate and work together to demonstrate an attitude of hard work and independence. Students can live an attitude of hard work and independence, so it is easy to draw conclusions based on their own appreciation.
\end{abstract}

\section{ABSTRAK}

Bisa dikatakan bahwa Pendidikan Aqidah Akhlak merupakan dasar untuk membentuk karakter siswa atau softskill. Menjadi tantangan tersendiri yang akan dihadapi dalam pembelajaran Aqidah Akhlak agar siswa mengamalkan ajaran agama, bukan skadar mengajaraknan teori sebagai pengetahuan saja, akan tetapi menuntut untuk mengarahkan anak didik agar memiliki kualitas iman, taqwa, dan akhlak Mulia. Mestinya proses pembelajaran harus dapat diimplementasikan dalam kehidupan nyata, Oleh arena itu, penning untuk menguatkan pelajaran Aqidah Akhlak, diperlukan metode dan strategi pembelajaran yang lebih kompleks dan tidak monoton. Dalam artikel ini penults menganalisa satu metode pembelajaran active learning, yaitu metode Sosiodrama pada materi kerja cerai dan mandiri. Penelitian ini merupakan penelitian library research menggunakan metode annalists isi (content analysis), dengan menganalisis dari dua summer yakni data primer dan data sekunder melalui pendekatan deskriptif analisis, dan interpretatif. Hasil penelitian ini menunjukkan bahwa implementasi metode Sosiodrama pada pembelajaran Aqidah Akhlak materi kerja keras dan mandiri, siswa dapat berpartisipasi aktif dan bekerjasama untuk memperagakan sikap karja keras dan mandiri. Peserta didik dapat menghayati sikap kerja keras dan mandiri, sehingga mudah mengambil kesimpulan berdasarkan penghayatannya sendiri.

This is an open access article under the CC-BY-SA license.

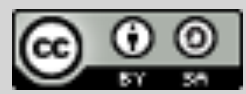




\section{Pendahuluan}

Metode pembelajaran merupakan langkah yang dipakai pendidik selama proses belajar. Pemilihan metode pembelajaran tentu harus menyesuaikan dengan perencanaan pembelajaran. Sehingga rangkaian pembelajaran yang dilakukan menuntut pendidik dan peserta didik saling menghargai, mendahulukan asas kebersamaan serta bersikap terbuka. Proses yang dijalankan tersebut akan menggali kompetensi secara optimal, baik dari sisi guru selaku pengajar dan siswa sebagai pebelajar. Atas dasar tersebut dapat dikatakan bahwa aktifitas belajar adalah satu di antara unsur terpenting dalam pendidikan, oleh sebab itu harus dirancang sejak awal dengan perencanaan yang sistematis dan inovatif.

Usman mengemukakan persoalan yang kerap kali ditemui dalam mempelajari agama Islam, yaitu langkah menyampaikan bahan ajar pada siswa dengan baik hingga hasil yang diperoleh berhasil dan tepat guna [1]. Persoalan lain yang kerap pula ditemui yakni guru agama kurang memperhatikan variasi metode mengajar dalam upaya meningkatkan mutu pembelajaran.

Pernyataan tersebut diperkuat oleh Mulyasa efektifitas dan efisiensi pembelajaran akan terwujud dengan menggunakan metode yang tepat dalam pembelajaran. Menggunakan metode yang bervariasi dapat membantu peserta didik dalam mencapai tujuan pembelajaran. Pengalaman belajar di sekolah bersifat fleksibel dan tidak kaku, serta menekankan aspek kreatifitas, rasa ingin tahu, pembinaan dan arahan pada tujuan kedewasaan anak didik [2].

Pada mata pelajaran Aqidah Akhlak materi pelajaran yang akan dibahas terkait pada ajaranajaran Islam yang telah Rasulullah ajarkan pada umatnya dari segi keimanan dan akhlak terpuji. Mata pelajaran ini sebagai upaya yang dilakukan untuk membimbing siswa supaya dapat memahami, menghayati, dan meyakini mengenai ajaran Islam, serta dapat mengimplementasikan dalam kehidupan keseharian siswa. Hal ini dikarenakan materi aqidah akhlak memiliki tujuan agar peserta didik dapat mendalami materi yang disampaikan sekaligus dapat mencerminkan atau mengimplementasikannya dalam hidup keseharian, dalam hal ini yaitu materi kerja keras dan mandiri. Materi tersebut merupakan materi yang sangat mudah diterapkan dalam metode sosiodrama, sehingga anak dapat praktek langsung secara aktif dan kolaboratif untuk memperagakan sikap kerja keras dan mandiri. Hal itu memudahkan siswa dalam memahami materi tersebut.

Pendidikan Aqidah akhlak merupakan serangkaian upaya yang dilakukan untuk menyiapkan siswa supaya dapat memahami mengenai ajaran yang diajarkan dalam islam, khusunya pada aspek keyakinan terhadap keagamaan (Tauhid) serta periaku yang berakhlakul karimah, terampil dalam melakukan ajaran yang diajarkan serta dapat menerapkan atau mengimplementasikannya dalam aktifitas harian dan kehidupan secara menyeluruh agar dapat mencerminkan ajaran Islam yang rahmatan lil 'alamin [3].

Menjadi tantangan terbesar dari mata pelajaran ini yaitu bagaimana siswa menerapkannya, bukan sekadar mengajarkan pengetahuan/teori agama saja, tetapi memberi arahan pada siswa untuk menjadi pribadi yang berkualitas; beriman, bertakwa, dan berakhlak mulia. Hal ini diperkuat dengan pernayataan muatan akhlak bukanlah sekadar menyampaikan pengetahuan/ materi terkait keislaman, tetapi cara membangun kepribadian peserta didik sehingga mempunyai kekokohan iman dan takwa, serta kehidupannya selalu diselimuti akhlak mulia di manapun dan kapanpun [4].

Dalam realita yang lebih sempit misalnya berdasarkan pengamatan penulis di SMP Muhammadiyah yang sudah menerapkan pendidikan karakter di sekolah, masih memiliki problematika keimanan dan akhlak siswa. Perilaku yang belum maksimal dalam menjalankan tuntunan ajaran agama Islam masih banyak ditemui. Seperti pelaksanaan shalat lima waktu, ketertiban, kesidiplinan, kebersihan, menjaga aurat, diantaranya yang masih terus menjadi tugas tidak terbatas yang harus dilakukan. Tentunya perilaku serupa dapat terjadi di sekolah manapun dan berpotensi besar jika tidak ada pendidikan agama secara serius. Itulah mengapa pendidikan agama memiliki peran strategis dalam mencapai pembentikan kepribadian insan mulia.

Praktik pembelajaran Aqidah Akhlak sebatas teori dan berbasis kelas atau sebatas pedagodis. Padahal pelajaran aqidah akhlak ini mencakup dasar kehidupan manusia secara luas. Bisa dikatakan bahwa pendidikan aqidah akhlak ini dasar untuk membentuk karakter siswa atau soft 
skill. Mestinya proses pembelajaran akidah akhlak itu terkoneksi dan terintegrasi dengan mapel lain bahkan menjadi landasan atas seluruh kegiatan sekolah yang tidak berada di kelas. Sebab itulah penguatan pelajaran aqidah akhlak menjadi sangat penting, diperlukan metode dan strategi pembelajaran yang lebih kompleks dan tidak monoton. Mengacu pada pemaparan di atas, jelaslah bahwa penggunaan metode belajar belumlah tercapai secara maksimal. Indikasinya terlihat dari masih minimnya kemampuan peserta didik dalam membangun cara berpikir kritis, kreatif, konstruktif, dan pengamalannya terlebih lagi pada pelajaran Akidah Akhlak.

Upaya mencapai tujuan pendidikan, pendidik sebagai pelaksanaan utama dalam aktifitas belajar di lapangan, memiliki andil signifikan dalam keberhasilan peserta didik. Untuk itu perlu adanya standar kompetensi pencapaian yang harus dimiliki peserta didik. Bagaimanapun idealnya sebuah kurikulum tanpa diiringi dengan kemampuan kapasitas guru untuk melaksanakannya dalam aktifitas pembelajaran, niscaya kurikulum tersebut seolah kehilangan kebermaknaannya [5].

Dalam rangka mewujudkan pembelajaran yang mendidik, maka guru perlu menguasai variasi metode pembelajaran, yang akan memberikan kebermaknaan dalam proses pembelajaran sehingga tercapainya belajar yang efektif dan efisien. Tentunya hal ini dapat terwujud dengan konsistensi guru dalam meningkatkan cakrawala pedagogisnya yang kukuh dan menguasai metode pembelajaran bagi siswa aktif. Pemanfaatan metode ini akan memberi tugas dan tanggung jawab yang setara antara pendidik dan peserta didik dalam proses pembelajaran [6].

Pemilihan metode pembelajaran yang tepat tentunya akan menciptakan iklim pembelajaran yang produktif, efektif, efisien. Efektif yang dimaksud membawa siswa untuk mengembangkan daya pikir bukan sekedar dapat diserap atau dihapal saja untuk beberapa saat. Upaya mencapai pembelajaran yang terarah dan efektif akan terwujud dengan penggunaan cara belajar menyenangkan dan bisa meningkatkan minat serta perolehan belajar peserta didik.

Metode bermain peran yang disebut juga sosiodrama akan memberi peserta didik kesempatan untuk melaksanakan kecakapan khusus yang dipelajari di dalam kelas [7]. Dengan metode ini hasil pembelajaran yang diharapkan mampu membawa siswa menguasai dan memperoleh hasil belajar yang diharapkan serta tercapainya tujuan yang ingin dicapai. Metode ini memiliki keunggulan di antaranya dapat mengembangkan daya pikir, karena siswa mampu mengingat materi dengan mempraktikkannya dalam bentuk cerita, sesuai yang tertulis di dalam naskah drama untuk kemudiaan dilakonkan secara bersamaan. Metode sosiodrama yang dianggap menarik bagi peserta didik, mampu menumbuhkan hasrat siswa. Hal tersebut dibuktikan penggunaan metode sosiodrama sebagai salah satu cara dalam pembelajaran Aqidah Akhlak, agar menghasilkan proses pelaksanaan pembelajaran yang berkualitas sesuai tujuan yang telah ditetapkan.

Sosiodrama merupakan teater, sandiwara, teater yang dijadikan model pembelajaran bermain peran yang bertujuan untuk memecahkan permasalahan yang berhubungan erat dengan kondisi sosial, istilah pembelajaran sosial karena dalam pembelajaran menggunakan hubungan masyarakat dn individu antar individu [8]. Model ini memiliki tujuan untuk meningkatkan kemampuan individu dalam menjalain hubungan dengan orang lain. George Shaftel menguangkapkan pembelajaran dengan menggunakan sosiodrama dirancang berdasarkan asumsi dari kondisi nyata yang dibentuk pada situasi pembelajaran.

Dengan Sosiodrama berupaya memecahkan masalah yang berhubungan dengan fenomena sosial, permasalahan yang menyangkut hubungan antar manusia. Demikian pula yang mengungkapkan bahwa sosiodrama digunakan untuk memberikan pemahaman tentang problematika sosial serta mengembangkan kecakapan siswa untuk memecahkan masalah. Sehingga dapat disimpulkan sosiodrama merupakan metode mengajar yang menngunakan dan memerankan tingkah laku tentang fenomena sosial yang memiliki makna dalam suatu pembelajaran [9].

Kelebihan dari metode Sosiodrama memberikan pengalaman bagi siswa untuk merasakan situasi yang kelak akan dirasakannya pada dunia nyata, membangun kreatifitas karena siswa dengan simulasi yang dilakukannya, membangun kepercayaan diri serta keberanian, memperkaya siswa dalam aspek pengetahuan dan keterampilan dalam menghadapi situasi sosial dan meningkatkan motivasi dalam pembelajaran. Sedangkan kelemahan metode sosiodrama 
diantaranya: pada hal tertentu tidak sesuai dengan kondisi kenyataan dilapangan, terkadang dapat terabaikan dari pembelajaran karena menjadi alat hiburan, serta rasa malu dan takut yang dipengaruhi pada faktor psikologis siswa [10].

Merujuk al-Qur'an surat An-Nahl ayat 125 pembelajaran merupakan sarana penyampaian pesan dengan menggunakan metode yang tepat, akan menentukan hasil pembelajaran yang baik pula. Metode Sosiodrama sebagai model pembelajaran bertujuan siswa menemukan makna diri dalam kehidupan sosial. Dengan bermain peran siswa akan memahami peran-peran yang berbeda. Diantara contoh kehidupan perilaku manusia yang berguna sebagai sarana bagi siswa. Metode ini dapat menggali perasaan siswa, mendapatkan inspirasi dan pemahaman yang berdampak pada sikap, persepsi dan nilai-nilai. Dengan bermain peran siswa dapat meningkatkan dan mempertajam kemampuan siswa dalam mengenal perasaan orang lain dan diri sendiri, serta menadpatkan bentuk prilaku baru untuk memecahkan masalah.

Dalam perspektif pendekatan pembelajaran aktif, metode sosiodrama merupakan pembelajaran aktif yang menciptakan suasana belajar menyenangkan, mendorong siswa untuk aktif belajar sejak awal melalui rangakaian atau tahapan-tahapan dari aktifitas pembelajaran dengan membangun kerja tim serta dalam waktu yang tidak lama membawat siswa untuk berpikir tentang materi yang ada dalam pembelajaran [11].

Pada pembelajaran aktif, siswa dikondisikan bukan sekedar sebagai penerima namun bersikap sebagai pemberi/pemeran aktif. Dengan paradigma tersebut siswa dituntut untuk mendapatkan jawaban dari berbagai pertanyaan-pertanyaan yang muncul dari sesama siswa itu sendiri. Siswa yang berusaha memacahkan masalah dari problematika yang diberikan oleh guru, tertarik dalam meraih informasi dan menguasai keterampilan dalam penyelesain tugas yang ada. Hal inilah yang menjadikan mereka tergerak untuk berpikir, bekerja, dan merasakan serta mengkaji dan memahami persoalan sesuai dengan nilai dan keyakinan yang dimilikinya [11].

Mahmud Yunus menyatakan tentang definisi Aqidah yang diartikan mengikat karena makna ikatan tersebut mengikat sedangkan dalam definisi teknis arti aqidah yakni iman atau keyakinan. Secara istilah (terminologi) akidah merupakan pokok-pokok dasar kepercayaan atau keyakinan hati seorang muslim yang bersumber ajaran Islam yang wajib dipegang oleh setiap muslim sebagai sumber keyakinan yang mengikat [12].

Sedangkan kata akhlak secara yang secara bahasa berarti tingkahlaku, tabiat atau budi pekerti. al-Gazali mendefinisikan akhlak sebagai sifat-sifat yang tertanam di jiwa dan melahirkan tindakantindakan dengan mudah tanpa memerlukan pertimbangan dan pemikiran, hakikat akhlak menurut Al-Ghazali harus mencakup dua syarat yaitu suatu perbuatan yang telah menjadi kebiasaan karena konstannya perbuatan yang dilakukan berulang dengan bentuk yang sama, dan perbuatan konstan itu tumbuh dari kesadaran diri sebagai perwujudan refleksi jiwa yang tidak adanya tekanan dari pihak lain [13].

Ruang lingkup pembelajaran Akidah Akhlak di Madrasah Tsanawiyah meliputi: pertama, aspek aqidah, Iman Kepada Rosul Allah, Nama-nama Rasul, Sifat-sifat Rasul, perilaku orang yang beriman kepada Rasul-rasul Allah. Kedua, aspek akhlak terpuji diantaranya ihklas, bertauhid, ta'at, khauf, taubat, tawakkal, ikhtiyaar, shabar, syukur, qanaa'ah, tawaadu', husnuzh-zhan, tasaamuh dan ta'aawun, berilmu, kreatif, produktif, dan pergaulan remaja. Ketiga, Aspek akhlak tercela meliputi syirik, kufur nifaaq, riya anaaniah, putus asa, ghadlab, tamak, takabbur, hasad, dendam, ghibah, namiimah dan fitnah [14]. Ruang lingkup ini menjadi acuan dalam turunan materi pelajaran yang akan dicapai oleh peserta didik dalam ragam aktifitas pembelajaran yang dirancang. Tujuan dari pembelajaran Akidah akhlak ini menumbuh serta mengembangkan akidah melalui pengamalan, penghayatan, pengetahuan, pembiasaan siswa tentang akidah hingga menjadi seorang muslim bertaqwa. Dengan kata lain terwujudnya kepribadian tersebut dapat menghindari akhlak buruk dalam kehidupan sebagai individu maupun sosial [14]. 


\section{Metode}

Penelitian ini menggunakan metode analisis konten (content analysis), dengan analisis yang isinya berupa kualitatif. Dalam perspektif metodologi kualitatif, salah satu pengukuran variabel adalah analisis isi, yang secara metodologi berdekatan dengan metode analisis data dan metode tafsir teks. Analisis isi ini lebih digunakan pada materi ilmu sosial [15]. Penelitian ini menggunakan metode analisis content pada jenis analisis isi kualitatif. Mengkonstruksi realitas dengan memperhatikan proses, peristiwa, dan otentitas dan memberi pemaknaan merupakan peranan yang dilakukan peneliti [16].

Penelitian ini menggunakan teori dari L. Silaberman tentang strategi pembelajaran active learning. Pembelajaran aktif merupakan proses belajar dengan melibatkan interaksi sisw, guru, dan lingkungan belajar. Dalam pembelajaran ini siswa lebih mandiri dan aktif dalam proses pembelajaran yang disampaikan oleh guru atau disebut student center [11].

Menurut Nana sudjana pembelajaran aktif merupakan suatu proses kegiatan pembelajaran yang siswanya terlibat secara aktif dan emosional sehingga siswa berperan dan berpartisipasi dalam suatu pembelajaran. Melakukan [17]. Berlandaskan dengan teori tersebut, peneliti ingin menganalisa dari tulisan yang ditulis oleh Cici Rina Nuringsih, Septia Fajar Astuti, Dewi Prasari Suryawati, Devi Anggraini, dan Abdullah[18]. Penelitian-penelitian tersebut yaitu berkaitan tentang implementasi metode Sosiodrama pada pembelajaran aqidah akhlak. Dari beberapa teori yang telah dipelajari oleh peneliti, maka peneliti juga harus melakukan innovasi tidak hanya terfokus pada implementasi metode sosiodrama akan tetapi metode-metode active learning lainnya seperti go to your post, Every one is a teacher here, Modelling the way, dan lainnya. Dimana metode tersebut menuntut keaktifan peserta didik dalam proses belajar.

\section{Hasil dan Pmbahasan}

\subsection{Analisis Karakteristik Materi Pelajaran Kerja Keras dan Mandiri}

Pada praktiknya, pembelajaran aqidah akhlak dalam hal ini materi kerja keras dan mandiri terdapat prinsip-prinsip yang menjadi acuan pokok untuk mencapai derajat substansi dari pembelajaran tersebut. Hal itu dapat dikonsepsikan ke dalam peta analisis karakteristik materi pelajaran yang digeneralisasikan dalam empat cakupan, yaitu Indikator, Ranah, KKO (Kata Kerja Operasional) dan Metode pembelajaran yang akan diterapkan. Adapun analisis karakteristik dalam materi pelajaran kerja keras dan mandiri yaitu sebagaimana pada tabel 1.

Pada ranah pertama Afektif (A1-receiving/attending) mengacu pada kecakapan untuk memperhatikan serta respon terhadap stimulus secara tepat dan kemampuan untuk menunjukkan penghargaan dan atensi pada orang lain.

Pada ranah kedua yaitu Afektif (A3-valueing) ranah ini mengacu pada urgensi dari values, penghargaan dan ketertarikan diri pada sesuatu serta terkait, penerimaan, penolakan dalam mengemukakan pendapat dan juga kemampuan untuk menyatakan yang baik dan kurang baik dari kegiatan dan mengekspresikan kedalam perilaku. Seperti misalkan peserta didik berserah diri kepada Allah setelah beriktiar atau berusaha. Artinya bahwa peserta didik dituntut meyakini bahwa usaha yang dilakukan tidak akan sia-sia. Sehingga dapat menghargai kekuasaan Allah.

Pada ranah ketiga, Afektif (A2-responsif) aktif dalam kegiatan pembelajaran dan memiliki motivasi yang baik untuk bereaksi dan mengambil tindakan. Dalam hal ini yaitu peserta didik menyelesaikan tugas kelompok dan mandiri tepat waktu.

Pada ranah keempat, Afektif (A3-penilaian/valueing) ranah ini berkenaan dengan memberikan nilai, rasa percaya dan menghargai terhadap suatu gejala atau stimulan tertentu. siswa tidak sekedar mau menerima nilai yang diajarkan akan tetapi berkemauan pula untuk menilai fenomena tersebut buruk atau baik. Dalam hal ini yaitu tidak mudah putus asa.

Pada ranah ke lima dan keenam, Kognitif (C1-pengetahuan) pada aspek ini berfokus pada kemampuan siswa untuk mengingat ulang terkait materi yang dipelajari, sebagai contoh pemahaman tentang istilah, fakta khusus, kecenderungan, konvensi, dan urutan, klasifikasi dan metodologi serta kategori . Tingkatan ini merupakan tingkatan terendah namun menjadi prasyarat bagi tingkatan selanjutnya. 
Tabel 1. Karakteristik Materi Pelajaran Kerja Keras dan Madiri

\begin{tabular}{|c|c|c|c|}
\hline \multirow{2}{*}{ Nomor } & \multicolumn{3}{|l|}{$\begin{array}{c}\text { Karateristik Materi Kerja } \\
\text { Keras dan Mandiri } \\
\end{array}$} \\
\hline & Indikator & Ranah & KKO \\
\hline 1 & $\begin{array}{l}\text { Bersyukur ketika berhasil } \\
\text { mengerjakan }\end{array}$ & Afektif (sikap religius) & Menyatakan (A1: menerima) \\
\hline 2 & $\begin{array}{l}\text { Berserah diri kepada Allah } \\
\text { setelah berusaha }\end{array}$ & Afektif (sikap religius) & Menunjukan (A3: menghargai) \\
\hline 3 & $\begin{array}{l}\text { Menyelesaikan tugas kelompok } \\
\text { dan mandiri tepat waktu }\end{array}$ & Afektif (sikap sosial) & Melaksanakan (A2: merespon) \\
\hline 4 & Tidak mudah putus asa & Afektif (sikap sosial) & Menunjukan (A3: menghargai) \\
\hline 5 & $\begin{array}{l}\text { Menjelaskan pengertian kerja } \\
\text { keras dan mandiri }\end{array}$ & Kognitif & Menjelaskan (C1: mengingat) \\
\hline 6 & $\begin{array}{l}\text { Menunjukan dasar hukum dalil } \\
\text { naqli dan aqli tentang kerja } \\
\text { keras }\end{array}$ & Kognitif & Menunjukan (C3: menerapkan) \\
\hline 7 & $\begin{array}{l}\text { Mengumpulkan contoh } \\
\text { perilaku kerja keras dan } \\
\text { mandiri }\end{array}$ & Psikomotorik & Mengumpulkan (P1: meniru) \\
\hline 8 & $\begin{array}{l}\text { Mendemonstrasikan contoh } \\
\text { perilaku kerja keras dan } \\
\text { mandiri }\end{array}$ & Psikomotorik & $\begin{array}{l}\text { Mendemonstrasikan/ } \\
\text { memainkan(P5: naturalisasi) }\end{array}$ \\
\hline
\end{tabular}

Pada ranah ketujuh, kognitif (C3-penerapan/application) yaitu focus pada kemampuan siswa dalam menerapkan informasi yang nyata dan aktual, dimana siswa memiliki kemampuan dalam menerapkan pemahaman dengan cara menggunakan secara nyata dalam kehidupan siswa. Pada jenjang ini siswa diharapkan dapat menerapkan konsep-konsep dan prinsip yang dimiliki pada kondisi dan situasi yang baru dan belum pernah diberikan sebelumnya.

Pada ranah kedelapan, Psikomotorik (P1-meniru) kategori meniruadalah kemampuan siswa untuk melakukan sesuatu melalui contoh yang dapat diamati walaupun belum dipahami makna ataupun hakikat dari keterampilan yang telah dicontohkan. Tugas siswa dalam ranah ini adalah mengumpulkan contoh-contoh perilaku kerja keras dan mandiri.

Pada ranah kesembilan, Psikomotorik (P5-naturalisasi) pada tahapan ini merupakan suatu kemampuan dimana seorang siswa dapat melakukan suatu keterampilan yang kompleks yaitu berkaitan terutama dengan gerakan interpretatif. Pada ranah Psikomotorik ini siswa mendemonstrasikan perilaku kerja keras dan mandiri dalam satu kegiatan pembelajaran.

\subsection{Analisis Metode Sosiodrama dalam Pembelajaran Aqidah Akhlak Materi Kerja Keras Dan Mandiri}

Dua jenis data diperoleh dalam penelitian sosiodrama ini, yaitu data analisis karakteristik materi pelajaran aqidah akhlak yaitu kerja keras dan mandiri. Dan data tentang analisis metode sosiodrama pada pembelajaran aqidah akhlak materi kerja keras dan mandiri.

Metode Sosiodrama mendorong pembelajaran sebagai permainan edukatif yang dimainkan secara bersamaan, tim/kelompok, pemebelajaran ini dilakukan dengan berpasangan yang berciri khas menantang [19]. Model Pembelajaran sosiodrama sebagai salah satu pembelajaran yang lebih diarahkan pada upaya memacahkan masalahyang kaitannya dengan hubungan antar sesame manusia atau interpersonal relationship yang berhubungan dengan kehidupan peserta siswa dalam kehidupan sehari-hari [20].

Beberapa Teknik pembelajaran sosiodrama agar lebih berperan aktif dalam suatu pembelajaran: (1) Membentuk tim, yaitu dengan membantu siswa untuk lebih mengenal sesama teman atau menciptakan semangat bekerjasama dan saling membantu, (2) Melakukan penilaian secara serentak yaitu dengan mempelajari tentang pengetahuan, sikap, dan pengalaman siswa, (3) 
Melibatkan belajar langsung yaitu menciptakan pembelajaran yang menarik untuk mengingkatkan motivasi dan minat belajar siswa terhadap pembelajaran [11].

Keberhasilan metode Sosiodrama tergantung pada kualitas dari sosiodraam ayang dilakukan dan dilakukannya analisis dalam setiap pembelajarannya. Selain itu keberhasilan pembelajaran sosiodrama bergantung pada persepsi siswa tentang peran yang dilakukan pada setiap individu terhadap konsep situasi yang nyata [21].

Metode sosiodrama memiliki langkah-langkah atau prosedur sebagai berikut: Tahap pertama, pemanasan. Pada tahap ini guru memberikan arahan dan ice breaking, guna menumbuhkan suasana senang dan membangun iklim siap belajar. Tahap kedua, memilih partisipan. Peserta didik diminta untuk membuat kelompok belajar dan memilih aktor atau partisipan yang akan menampilkan contoh perilaku kerja keras dan mandiri. Pemilihan ini dialkukan secar independen guna membangun rasa kepercayaan diri peserta didik dan memberikan kepercayan dalam menentukan pilihan [22].

Pada tahapan berikutnya yang ketiga, menyiapkan pengamat (observer). Peserta didik menyiapkan pengamat yang bertugas mengamati dan menyiapkan segala sesuatu yang dibutuhkan dalam mendemostrasikan perilaku kerja keras dan mandiri. Tahap keempat, menata panggung. Peserta didik masing-masing kelompok menata dan setting panggung di depan kelas agar akting bermain peran berjalan sesuai tujuan yang diinginkan. Tahapan ini memberi ruang kreatifitas dan imajinasi peserta didik dalam menciptakan suasana pendukung dalam pembelajaran bermain peran.

Tahap kelima, memainkan peran atau drama. Peserta didik mulai bermain peran atau acting dalam rangka mempraktikkan/ mendemonstrasikan contoh perilaku kerja keras dan mandiri. Pada tahapan ini yang menjadi fokus utama sesuai dengan tuntutan materi pelajaran agar tercapainya tujuan yang telah ditetapkan. Tahap keenam, diskusi dan evaluasi. Pada tahap ini peserta didik melakukan diskusi dan evaluasi terkait pentas atau acting terkait perilaku kerja keras dan mandiri yang telah dilakukan sebelumnya.

Tahap ketujuh, memainkan peran ulang. Peserta didik memainkan peran ulang tentang contoh perilaku kerja keras dan mandiri yang kedua kalinya setelah diberikan masukan dari hasil pada tahapan sebelumnya yakni diskusi dan evaluasi. Tahap kedelapan, diskusi dan evaluasi kedua. Peserta didik mengadakan diskusi dan evaluasi yang kedua kalinya agar kegiatan bermain peran berjalan lebih baik. Sehingga dapat membandingkan antara pentas kedua dengan pentas yang pertama. Sehingga dapat mengoreksi kesalahan-kesalahan ketika bermain peran.

Tahap kesembilan, berbagi pengalaman dan kesimpulan. Peserta didik melakukan aktifitas dengan kelompoknya untuk berbagi pengalaman dan peserta didik dapat menyimpulkan tentang kegiatan belajar dengan metode Sosiodrama yang telah dilakukan.

Berdasarkan kerja ilmiah diatas peneiltian ini dapat disimpulkan bahwa hasil analisis karakteristik pelajaran aqidah akhlak materi kerja keras dan mandiri dilakukan dengan merujuk pada kompetensi isi, indikator, ranah, dan KKO yang disesuaikan dengan kurikulum 2013. Hasil analisis model pembelajaran sosiodrama pada pembelajaran aqidah akhlak pada materi kerja keras dan mandiri dilakukan dengan beberapa tahapan atau prosedur dianataranya yaitu: tahap pemanasan, memilih partisipan, menata panggung, menyiapkan penonton atau observer, diskusi memainkan peran, dan evaluasi, memainkan peran ulang, diskusi dan evaluasi kedua, dan berbagi pengalaman dan kesimpulan dari sosiodrama yang telah diperankan.

\section{Kesimpulan}

Berdasarkan hasil pembahasan dalam penelitian ini maka dapat disimpulkan bahwa hasil analisis karakteristik pelajaran aqidah akhlak materi kerja keras dan mandiri dilakukan dengan merujuk pada kompetensi isi, indikator, ranah, dan KKO yang disesuaikan dengan kurikulum 13.

Hasil analisis metode sosiodrama pada pembelajaran aqidah akhlak pada materi kerja keras dan mandiri dilakukan dengan beberapa tahapan atau prosedur dianataranya yaitu: tahap pemanasan, memilih partisipan, menyiapkan pengamat (observer), menata panggung, memainkan peran, diskusi dan evaluasi, memainkan peran ulang, diskusi dan evaluasi kedua, dan 
berbagi pengalaman dan kesimpulan. Dengan demikian, implementasi metode Sosiodrama pada pembelajaran Aqidah Akhlak, siswa dapat berpartisipasi aktif dan bekerjasama untuk memperagakan sikap kerja keras dan mandiri. Peserta didik dapat menghayati sikap kerja keras dan mandiri, sehingga mudah mengambil kesimpulan berdasarkan penghayatannya sendiri.

\section{Referensi}

[1] S. \& M. B. U. Nurdin, Guru Profesional dan Implementasi Kurikulum. Jakarta: Cipta Press, 2020.

[2] P. A. I. Melalui and M. Kelas, "Kegiatan Akademik Berupa Perencanaan, Pelaksanaan Dan Penilaian Pembelajaran.," vol. 1, no. 2, p. 163, 2017.

[3] M. M. Rasyid, "Islam Rahmatan Lil Alamin Perspektif Kh. Hasyim Muzadi," Epistemé J. Pengemb. Ilmu Keislam., vol. 11, no. 1, pp. 93-116, 2016, doi: 10.21274/ epis.2016.11.1.93-116.

[4] Sungkowo, "Konsep Pendidikan Akhlak: Komparasi Pemikiran Al-Ghazali dan Barat," Nur El-Islam, vol. 1, no. 1, pp. 33-62, 2014.

[5] Tabroni, "Upaya Menyiapkan Pendidikan Yang Berkualitas," Pendidikan, no. 5, pp. 54-67, 2013.

[6] M. Afandi, E. Chamalah, and O. P. Wardani, Model Dan Metode Pembelajaran Di Sekolah, vol. 392, no. 2. 2013.

[7] M. Pelajaran, F. Di, and M. Aliyah, "Mata Pelajaran Fiqih di Madrasah Swasta Diajukan Untuk Melengkapi Tugas-tugas dan Memenuhi Syarat- Syarat Guna Memperoleh Gelar Sarjana Pendidikan Agama Islam ( S . PD ) NPM : 1501020066,” 2019.

[8] S. Ulfa, Maria., "Terampil Memilih Dan Menggunakan Metode Pembelajaran," Suhuf, vol. 30, no. 1, pp. 35-56, 2018.

[9] F. Npm, P. A. Islam, and I. Keguruan, "Terhadap Hasil Belajar Mata Pelajaran Pendidikan Agama Islam Siswa Kelas X Sma N 1 Batanghari Lampung Timur Tahun Pelajaran,” 2019.

[10] K. Kinestik, S. Dalam, and P. Ips, "Kata Kunci: Sosiodrama, Kecerdasan Kinestetik 1,” pp. $1-18,2016$.

[11] M. L. Silberman, Active Learning. Terjemahan Raisul Muttaqien, 101 Cara Belajar Siswa Aktif. Bandung: Nusa Media., 2006.

[12] E. Y. Kodina, B. Rama, A. R. Getteng, and N. Said, "Hakikat Materi Akidah Perspektif Pendidikan Agama Islam Dalam Kurikulum Sekolah Dasar Kelas V," J. Diskurs. Islam, vol. 04, no. 03, p. 529, 2016.

[13] Y. Suryadarma and A. H. Haq, "Pendidikan Akhlak Menurut Imam Al-Ghazali," At-Ta'dib, vol. 10, no. 2, pp. 362-381, 2015.

[14] S. Sy, H. Hairunnisa, and L. Rahmawati, "Pembelajaran Akidah Akhlak di Madrasah Tsanawiyah Negeri Model Darussalam Martapura Kabupaten Banjar," Tashwir, vol. 1, no. 2, pp. 81-94, 2014, doi: 10.18592/jt.v1i2.164.

[15] M. Maryono, "Analisis Pedagogical Content Knowledge (Pck) Guru Matematika Dan Praktik Pembelajarannya," JP2M (Jurnal Pendidik. dan Pembelajaran Mat., vol. 1, no. 2, p. 58, 2020, doi: 10.29100/jp2m.v1i2.200.

[16] G. Resbiantoro, "Analisis Pedagogical Content Knowledge (Pck) Terhadap Buku Guru Sd Kurikulum 2013," Sch. J. Pendidik. dan Kebud., vol. 6, no. 3, p. 153, 2016, doi: 10.24246/ j.scholaria.2016.v6.i3.p153-162. 
[17] N. Sudjana, Cara Belajar Siswa Aktif dalam Proses Belajar. Bandung: Sinar Baru Algesindo, 1996.

[18] Abdullah., "Metode Sosiodrama Dalam Pembelajaran Aqidah Akhlak Siswa Kelas VII Di Mts Pondok Pesantren.," Universitas Muhammadiyah Palembang., 2015.

[19] M. T. O. D. Sosiodrama and D. Pembelajaran, "Otch Abduliab."

[20] R. F. Fauziyah, A.Y \& Pradipta, "Implementasi Metode Sosiodrama dalam Mengasah Pelafalan Kalimat Anak Tunarungu Kelas XI.," J. Ortopedagogia, vol. 4, no. 2, pp. 82-86, 2018.

[21] I. T. A. Awaliyah, A. Taufiq, and A. Hafina, "The Effectiveness of Sociodrama to Improve Students' Anger Management Skills," Islam. Guid. Couns. J., vol. 2, no. 2, pp. 56-65, 2019 , doi: 10.25217 /igcj.v2i2.397.

[22] N. K. D. Tristiantari, "an Effect of Sociodrama Method Implementation in Students Language Skill At Fourth Grade Elementary School in Cluster Xii of Buleleng District," $J$. Educ. Technol., vol. 1, no. 1, p. 45, 2017, doi: 10.23887/jet.v1i1.10083. 